Eskişehir Osmangazi Üniversitesi IißBF Dergisi

Ağustos 2019, C. 14, S. 2, 277 - 290.

Başvuru : 08.03.2018

Kabul : :04.04.2019

\title{
Türkiye Tarım Kredi Kooperatifleri için Kurumsal Performans Karnesi Önerisi ${ }^{1}$
}

Abdulkadir Fasal ${ }^{2}$

Özlem Balaban ${ }^{3}$

Türkiye Tarım Kredi Kooperatifleri için Kurumsal Performans Karnesi Önerisi

Öz

Bu çalışmada, ülkemiz tarım sektörü açısından önemli konumda bulunan kooperatiflerin kurumsal performanslarında artış sağlayacak, yöneticiler için karar verme süreçlerine katkıda bulunacak ve kooperatiflerin kendi yapılarına uyarlayarak kullanabilecekleri çok boyutlu ölçme ve değerlendirme sistemini baz alan kurumsal performans karnesi oluşturulması amaçlanmıştır. Çalışma kapsamında verilerin elde edilmesinde kullanılan anket formu yöneticilerden oluşan 5 kişilik bir çaıışma grubu ile yapılan 9 haftalık çalışmalar sonucu oluşturulmuştur. Sonrasında anket formu Tarım Kredi Kooperatifleri Merkez Birliği ve 17 Bölge Birliğinde çalışan 140 yöneticiye gönderilmiştir. Yöneticiler tarafından 105 ankete geri dönüş yapılmıştır. Çalışma sonucunda tarımsal kooperatiflerde finansal ve ortak boyutunun ön planda olduğu, öğrenme ve gelişme boyutunun arka planda kaldığı tespit edilerek, konuya yönelik çözüm önerileri geliştirilmiştir.

Anahtar Kelimeler: Tarımsal Kooperatif, Kurumsal Performans Karnesi, Türkiye Tarım Kredi Kooperatifleri

\begin{abstract}
Proposal for Balanced Scorecard for Agricultural Credit Cooperatives in Turkey

Abstract

In this study, the purpose was to create an Institutional Performance Report based on multidimensional measurement and evaluation system, which will increase the institutional performances of cooperatives, which are important for agricultural sector, which will contribute to the decision-making processes of managers, and which will be adapted to the structures of cooperatives. The questionnaire that was used to obtain the study data in the scope of the study was created as a result of a 9-week effort with a 5-people workgroup of managers. The questionnaire was sent to 140 managers who worked at Central Union of Agricultural Credit Cooperatives and 17 Regional Units. A total of 105 questionnaires were returned by the managers. At the end of the study, that the financial and common aspects are in the foreground in agricultural cooperatives, learning and development aspects are background was stated and solution suggestions were developed.
\end{abstract}

Keywords: Agricultural Cooperative, Balanced Scorcard, Turkey Agriculture Credit Cooperatives

\section{Giriş}

Etkin yönetimin ve bilginin önem kazandığı, değişimin kaçınılmaz olduğu rekabet ortamında işletmelerin yaşamlarını sürdürebilmeleri için etkin bir performans yönetim sistemi kurmaları gerekmektedir. İşletmeler 20. Yüzyılın son çeyreğine kadar sadece finansal verilere göre değerlendirmenin yapıldığı geleneksel yöntemler olarak nitelendirilen performans ölçüm sistemlerini kullanmışlardır. Kurumsal performans karnesi bu bağlamda geleneksel ölçüm sistemlerinin yetersizliklerini gidermek amacıyla getirdiği yenilikler ile önem kazanmıştır.

Kurumsal performans karnesi diğer performans ölçüm sistemlerinde dikkate alınmayan işletmenin maddi olmayan varlıklarının fark edilmesini sağlamakta, finansal boyutun yanı sıra müşteri, iç süreçler, öğrenme ve gelişme boyutlarını da ele almakta ve bu boyutlar arasında

\footnotetext{
${ }^{1}$ Bu çalışma Sakarya Üniversitesi İşletme Enstitüsü İşletme Anabilim Dalı́nda Doç Dr. Özlem Balaban danışmanlığında Abdulkadir Fasal tarafından "Türkiye Tarım Kredi Kooperatifleri İçin Kurumsal Performans Karnesi Önerisi" ismiyle tamamlanarak 29.03.2019 tarihinde savunulan doktora tezinden türetilmiştir.

2 Dr., Türkiye Tarım Kredi Kooperatifleri, abdulkadir_fasal@hotmail.com, Yazar ORCID bilgisi: http://orcid.org/00000002-6997-3236

3 Doç. Dr., Sakarya Üniversitesi İşletme Fakültesi, İşletme Bölümü adiguzel@sakarya.edu.tr, Yazar ORCID bilgisi: http://orcid.org/0000-0001-6830-5052
} 
işletmenin vizyon ve amaçlarını gerçekleştirmesi noktasında bir dengenin sağlanması gerektiğini vurgulamaktadır (Kaplan ve Norton, 2015).

Tarım sektörü hem ekonomik açıdan hem stratejik açıdan ülkeler için büyük önem taşımaktadır. Gelişmiş ülkelerde kamu ve özel sektörün ardından 3. Sektör olarak tanımlanan kooperatifler (GTB, 2012) özellikle küçük aile işletmelerinin olduğu tarım sektöründe finansman imkânlarının genişletilmesine, sermaye birikiminin sağlanmasına, yeni istihdam alanları oluşturulmasına, üretimin arttırılmasına, tarımın ve küçük çaplı üretimlerin sanayiye entegrasyonuna, piyasaların olumlu yönde regülâsyonuna, girişimcilik ve ortak iş yapma kültürünün geliştirilmesine ve dolayısıyla ülkemizin bir bütün olarak kalkınmasına önemli ölçüde katkı sağlamaktadır. Birçok farklı nitelik taşıyan maddi ve maddi olmayan kaynak ve kabiliyetlerin bir arada olduğu kooperatif işletmelerinin başarılı bir şekilde yönetilmesi ve yaşamlarını devam ettirebilmeleri için çok boyutlu ölçme ve değerleme sistemleri gerekmektedir.

Bu çalışmanın amacı, ülkemiz için stratejik bir konumda bulunan tarım sektörü için kritik öneme sahip kooperatif işletmelerinin geleceği hedefleyerek süreklilik sağlayabilmesi için kurumsal performansta artı̧̧ sağlayacak, kendilerine özgü, çok boyutlu bir ölçme ve değerlendirme sisteminin, kurumsal performans karnesi yöntemiyle ölçülmesini sağlayacak örnek bir model önerisi geliştirmektir.

Türkiye Tarım Kredi Kooperatiflerinin organizasyon yapısı Merkez Birliği, Bölge Birlikleri ve Birim Kooperatiflerden oluşmaktadır. Merkez Birliği kooperatifler için gerekli olan finansmanın sağlanması, kurumsal stratejilerin belirlenmesi ve uygulanması, insan kaynakları politikasının belirlenmesi vb. işlevleri yerine getirmektedir. Bölge Birlikleri ise kendisine bağlı bulunan kooperatifler arasında koordinasyon sağlanması, kooperatiflerin ihtiyaç duyduğu girdilerinin zamanında tedarik edilmesi, kooperatifler adına ödeme işlemlerin ve vergi mevzuatından doğan sorumluklarının yerine getirmektedir. Birim Kooperatifler ise ortakların ve diğer üreticilerin ihtiyaç duyduğu, girdilerin tedarik edilerek ortaklara peşin veya kredili olarak satılmasını ve ortakların üretmiş oldukları ürünlerin pazara ulaştırılması işlevini yerine getirmektedir.

Çalışmada öncelikle kurumsal performans karnesi ve kooperatif işletmeleri kavramsal olarak ele alınmaktadır. Sonrasında kooperatif işletmelerinin kendi kurumsal performans karnesini oluşturma sürecinde kullanabileceği örnek amaç ve ölçütler çalışmadan elde edilen veriler doğrultusunda değerlendirilerek tablolar halinde özetlenmiştir.

\section{Kavramsal Çerçeve}

\subsection{Kurumsal Performans Karnesi (KKP) Kavramı}

Ölçülemeyen yönetilemez ilkesini temel alan kurumsal performans karnesi, organizasyonlarda vizyon ve stratejilerin uygulamaya dönüştürülmesini sağlayan bir araç olarak görülmektedir. Performans Karnesi modeli ilk olarak Kaplan ve Norton tarafından 1992 yılında Harvard Business Review"da yayınlanan bir makale ile tanıtılmış olup, "The Balanced Scorecard - Measures That Drive Performance" başlığı ile literatüre girmiştir (Wilson vd., 2004: 54)

Kaplan ve Norton (1992), Kurumsal performans karnesini (KKP), örgütün misyonunu ve stratejilerini anlaşılabilir bir performans ölçüm setine dönüştürerek ifade eden, stratejik performans ölçümü ve yönetimi için bir çerçeve oluşturan, ölçme esasına dayalı bir stratejik performans yönetim sistemi olarak tanımlamıştır. Bose (2004: 457) ise," Performans Karnesini, işletmenin misyonunu esas alarak, stratejik amaçlarını ve hedeflerini gerçekleştirilebilmesi için performansını izlemek ve faaliyet sonuçlarını ölçülebilir hale getirmek amacıyla kullanılan bir 
analiz tekniği olarak ifade etmiş̧ir. Kurumsal performans karnesi (KKP), strateji ve vizyonu işletmenin merkezine koymakta ve bunları ölçülebilir hedeflere dönüştürmektedir (Letza, 1996: 58; Griffiths, 2003: 70).

Kurumsal performans karnesi öncelikle geleneksel ölçme yaklaşımlarının eksikliklerini gidermek ve ölçme sorunlarına pratik çözümler bulabilmek için geliştirilmiştir( Perkins vd.,2014: 149). Bu bağlamda bir örgütün finansal performansını; müşteri, iç süreçler ve öğrenme/gelişme performanslarıyla dengeleyerek, uzun vadede rekabetçi başarıyı devam ettirebilmek için daha hangi alanlarda ölçüm yapması gerektiği konusunda geçerli olan bir ölçme sistematiği geliştiren stratejik yönetim aracıdır (Albright vd., 2015: 45).

Kurumsal performans karnesi, Wake (2015)' e göre diğer performans ölçüm modellerinde kullanılan finansal göstergeleri de içerir; fakat finansal göstergeler tek başlarına kullanıldıklarında yalnızca geçmiş dönem hakkında bilgi verir ve işletmenin geçmiş dönem performansını gösterir. Bu bağlamda işletmelerin yaşamlarını devam ettirebilmeleri, stratejilerini gerçekleştirebilmeleri, başarıyı kalıcı ve sürekli kılabilmeleri için finansal veriler dışında müşteri memnuniyeti, çalışan memnuniyeti, öğrenme ve gelişme, yaratıcılık, içsel süreçler, teknolojik yenilikler gibi finansal olamayan verileri de dikkate almaları gerekmektedir (Lawrie ve Cobbold, 2004: 611).

Kaplan ve Norton yapmış oldukları çalışmalar neticesinde kurumsal performans karnesini dört boyuta indirgemiştir. Kurumsal performans karnesinin bu dört boyutu finansal boyut, müşteri boyutu, iç süreçler boyutu, öğrenme ve gelişme boyutu olarak sıralanmaktadır. Şekil'1 de gösterilen bu dört farklı açı kurumsal performans karnesinin ana çerçevesini oluşturmaktadır (Kaplan ve Norton, 2015: 9).

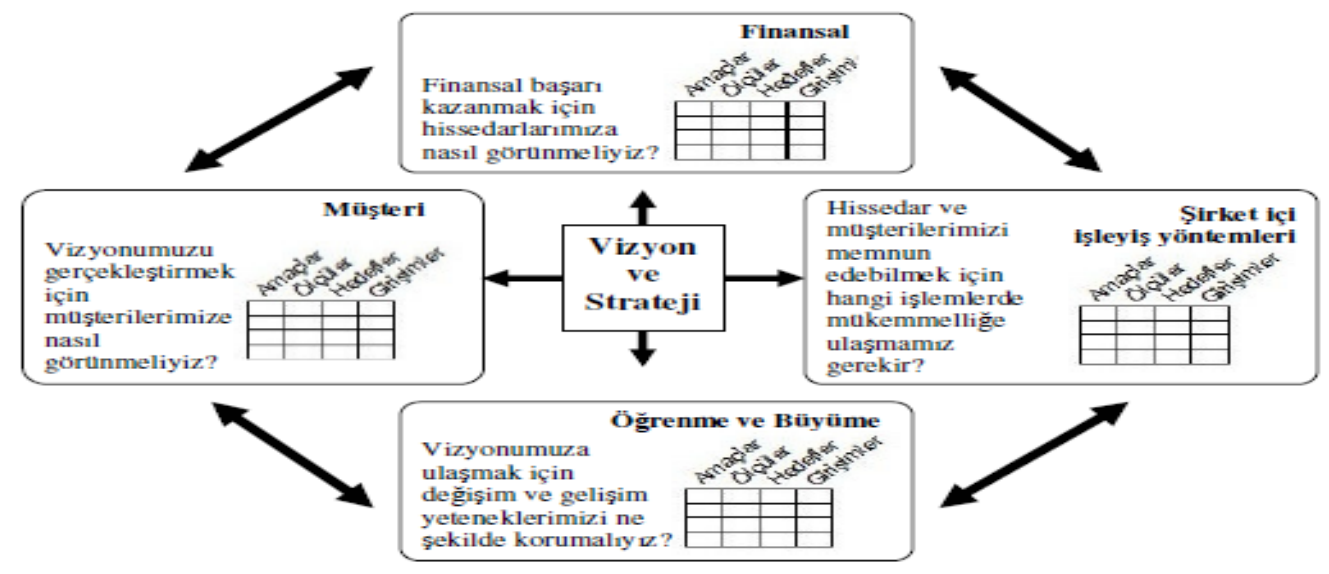

Şekil 1: Kurumsal Performans Karnesinin Boyutları

Kaynak: Kaplan ve Norton, 2015: 10

Kurumsal performans karnesi geçmişi kapsayan, aynı zamanda geleceğe yönelik, içsel ve dışsal performans ölçütlerini, çok boyutlu bir yaklaşımla ele almaktadır. Finansal boyut geçmişle ilgili ölçütleri ortaya koyarken, öğrenme ve gelişme boyutunun içerdiği ölçütler ileriye dönük ölçütlerdir. Kurumsal performans karnesi, finansal ölçümü, yönetim ve işletme performansının özet bilgisi olarak muhafaza ederken, aynı zamanda mevcut müşteriler, şirket içi yöntemler, çalışanlar ve sistemin performansını uzun dönemli finansal başarıyla ilişkilendiren daha genel ve entegre ölçü birimlerine de önem vermektedir (Kaplan ve Norton, 1993: 4). 


\subsection{Kooperatif Kavramı}

Kooperatif, asıl amacı kâr elde etmek olan işletmelerden farklı bir girişim türü olarak değerlendirilmektedir (Russell vd., 2017). Szoabo (2005: 3) kooperatifin esas amacını, kendisinin hem sahibi hem de müşterisi olan ortaklarının ihtiyaçlarını karşılamak ve gelirlerini arttırmak olduğunu belirtmektedir. Kârlarını her zaman en yükseğe çıkarmayı düşünen işletmelerde amaç hissedarlarına hizmet etmek iken, kooperatiflerde sürdürülebilir bir şekilde ortaklarına hizmet etmektir (MacPherson, 1994: 8). Kooperatifi kavramsal olarak ifade etmeye yönelik birçok tanım söz konusudur. Uluslararası Kooperatif Birliği (ICA) kooperatifi, kişilerin gönüllü olarak birleşip ortak ekonomik, sosyal ve kültürel ihtiyaçlarını ve beklentilerini müştereken sahip olunan ve demokratik kurallarla yönetilen bir işletme vasıtası ile karşılamak için oluşturdukları özerk bir kuruluş olarak tanımlamaktadır (ICA, 1995). Bu tanımda yer alan gönüllü olarak birleşme, müştereken sahip olma, demokratik kurallarla yönetme, ortak ihtiyaçlarının karşılanması, özerk bir kuruluş gibi ifadeler kooperatif işletme modelinin diğer işletme türlerinden farklılığını açık bir şekilde göstermektedir (Polat, 2017: 19).

\section{Araştırmanın Yöntemi}

\subsection{Araştırmanın Amacı}

Kurumsal performans karnesinin oluşturulması ve uygulanmasına pek çok alanda farklı çalışmalar (Pazarçeviren vd., 2015; Erkul vd., 2015; Yılmaz ve Gudil, 2016; Gençay, 2014; Öztuna, 2014; Usta, 2012; Gencer ve Çetin, 2011; Yıldız vd., 2013) yapılmış olmasına rağmen ülkemizde özellikle tarım sektörü açısından önemli bir yere sahip olan kooperatiflere yönelik herhangi bir çalışmaya rastlanılmamıştır. Bu noktadan hareketle çalışmada kooperatif işletmelerinde kurumsal performans karnesinin uygulanabilirliğinin araştırılması, kurumsal performans karnesi oluşturulmasında kullanılabilecek amaçlar ve bu amaçları test etmeye yönelik ölçütlerin belirlenmesi ve sonucunda her bir kooperatif işletmesinin kendine özgü yapılarına uyarlayabilecekleri ve kurumsal performans karnelerini tasarlamada kullanabilecekleri bir modelin oluşturulması amaçlanmaktadır.

\subsection{Metod}

Araştırmanın içeriğini oluşturan veriler anket yöntemiyle elde edilmiştir. Bu kapsamda katılımcılara, "Bir kooperatif işletmesinin kurumsal performans karnesinin dört boyuttaki stratejik hedefleri ve amaçları neler olmalıdır?", "Bu hedeflere ve amaçlara ulaşılıp ulaşılmadığını test etmede kullanılabilecek ölçütler neler olmalıdır?" şeklinde iki soru yöneltilmiştir. Ayrıca anket formunda her bir boyutun son kısmında yöneticilerin farklı görüş / önerilerini belirtmeleri amacıyla sorular tekrarlanmış ve kendi ifadeleri ile amaç ve ölçütlere eklemeler yapabilecekleri belirtilmiştir.

Çalışmada tarımsal kooperatiflerde örgütsel performansın ölçülmesi ve değerlendirilmesinde kullanılabilecek kurumsal performans karnesi oluşturulması kapsamında veriler anket yöntemiyle toplanmıştır. Anket formunda yer alan stratejik amaç ve hedefler ile bunları test edecek ölçütlerin belirlenmesi kapsamında Tarım Kredi Kooperatiflerinde çalışan iki bölge müdür yardımcısı, bir bölge birliği kontrolörü, bir yönetmen ve bir yönetmen yardımcısı olmak üzere toplamda beş kişinin katıldığı 9 haftalık süreçte haftada 2 gün ve 2 saat süren çalışmalar yapılmıştır. Elde edilen anket formu uygulama öncesinde geçerlilik ve güvenirlilik konusunda 4 akademisyen tarafından ayrı ayrı incelenmiş ve sonrasın da 4 yöneticinin görüşleri alınmıştır. Sonrasında örneklem içerisinde yer alan on yöneticiye pilot uygulama yapılarak, soruların anlaşılırlığı ve anket tamamlama süresine ilişkin bilgiler elde edilmiştir. 
Kurumsal performans karnesinin hedef ve ölçütleri kooperatiflerin vizyon ve stratejileri göz önüne alınarak belirlendiğinden bu noktada karar vericiler Genel Müdürlük ve Bölge Birliklerindeki orta ve üst düzey yöneticilerdir. Bu bağlamda çalışmamızda örneklem belirleme yöntemi olarak olasılığa dayalı olmayan örnekleme tekniklerinden kasti (kararsal) örnekleme yöntemi kullanılmış olup örneklem olarak Genel Müdürlük ile Sakarya, Tekirdağ, Balıkesir, Ankara, Kütahya, İzmir, Samsun, Trabzon, Konya, Kayseri, Mersin, Antalya, Erzurum, Malatya, Şanlıurfa, Sivas ve Gaziantep illerinde bulunan 17 bölge müdürlügünde çalışan yöneticiler belirlenmiştir. Anket formlarının eksiksiz ve doğru şekilde doldurulabilmesi için Genel Müdürlük ve 17 Bölge Müdürlüğünden birer kişi belirlenerek, bu kişilere anketin nasıl uygulanacağı anlatılmıştır. Anket formları posta yoluyla belirlenen kişilere gönderilerek ilgili birimlerdeki yöneticilerle anketlerin yapılması ve verilerin toplanması sağlanmıştır. Türkiye Tarım Kredi Kooperatifleri Genel Müdürlüğü ve 17 Bölge Müdürlüğünde çalışan 140 yöneticiye anket gönderilmiştir. Anketlerin 105 tanesine geri dönüş yapılmıştır. Çalışmadan elde edilen veriler ışığında kooperatifler için örnek bir kurumsal performans karnesinde yer alacak amaç ve ölçütler belirlenmiştir.

iki bölümden oluşan anket formunun birinci bölümünde kişinin kurumdaki pozisyonu ve çalışma yılının yanı sıra kurumdaki mevcut uygulamanın yeterli olup olmadığı sorgulanmıştır. İkinci bölümde ise kooperatif işletmelerinde uygulanabilecek kurumsal performans karnesi modeline ilişkin finans, müşteri, iç süreçler ve öğrenme gelişme boyutu olmak üzere dört boyuttaki amaç ve ölçütleri belirlemeye yönelik değerlendirmelere yer verilmiştir.

\subsection{Araştırmanın Evren ve Örneklemi}

Kurumsal performans karnesinin kooperatif işletmelerinin kurumsal performanslarını ölçme ve değerlemede uygun ve faydalı bir model olacağı düşünülerek uygulamanın kooperatif işletmelerinde gerçekleştirilmesine karar verilmiştir. Ayrıca yapılan çalışmalarda kooperatif işletmeleri ile ilgili kurumsal performans karnesi uygulamalarına rastlanmaması çalışmanın özgünlüğünü kuvvetlendiren bir unsur olarak kabul edilmektedir.

Araştırmanın evrenini Türkiye Tarım Kredi Kooperatifleri Merkez Birliği, Bölge Birliği ve birim kooperatiflerde çalışan yöneticiler oluşturmaktadır. Kurumsal performans karnesinin hedef ve ölçütleri kooperatiflerin vizyon ve stratejileri göz önüne alınarak belirlendiğinden bu noktada karar vericiler Genel Müdürlük ve Bölge Birliklerindeki orta ve üst düzey yöneticilerdir. Bu bağlamda çalışmamızda örneklem belirleme yöntemi olarak olasılığa dayalı olmayan örnekleme tekniklerinden kasti (kararsal) örnekleme yöntemi kullanılmış olup örneklem olarak Genel Müdürlük ile Sakarya, Tekirdağ, Balıkesir, Ankara, Kütahya, İzmir, Samsun, Trabzon, Konya, Kayseri, Mersin, Antalya, Erzurum, Malatya, Şanlıurfa, Sivas ve Gaziantep illerinde bulunan 17 bölge müdürlüğünde çalışan yöneticiler belirlenmiştir. Yöneticiler genel müdürlükte; genel müdür, genel müdür yardımcısı, daire başkanı, birim müdürü, müfettiş ve uzmandan oluşmaktadır. Bölge Birliklerinde ise bölge müdürü, bölge müdür yardımcısı, kontrolör ve uzmandan oluşmaktadır.

\section{Bulgular}

Tarımsal kooperatif işletmelerinde, kurumsal performans karnesi oluşturulmasına yönelik bu çalışmanın bulguları, Tarım Kredi Kooperatiflerinde kapsam dışı olarak nitelendirilen yöneticilerin deneyim ve değerlendirmelerini içermektedir. Kurumsal performans karnesinin her bir boyutu için ayrı ayrı oluşturulan amaçlar ve ölçütlere ilişkin ulaşılan bulguların analizi ve yorumlanması kurumsal performans karnesinin temelini oluşturacaktır. 
Eskişehir Osmangazi Üniversitesi iißB Dergisi

Tablo 1: Katılımcıların Kurumdaki Konumu

\begin{tabular}{l|ll}
\hline \multicolumn{3}{c}{ Kurumdaki Konumu } \\
\hline Konumu & Frekans & $\%$ \\
\hline Genel Müdür Yrd. & 2 & 1,90 \\
Daire Başkanı & 3 & 2,86 \\
Birim Müdürü & 9 & 8,57 \\
Bölge Müdürü & 14 & 13,33 \\
Bölge Müdür Yrd. & 33 & 31,43 \\
Uzman & 9 & 8,57 \\
Müfettiş & 8 & 7,62 \\
Kontrolör & 27 & 25,71 \\
\hline Toplam & 105 & 100,00 \\
\hline
\end{tabular}

Ankete katılan yöneticilerin \%31,43'ünün Bölge Müdür Yardımcısı \%25,71'nin Kontrolör ve \%13,33'ünün Bölge Müdürü, \%8,57'sinin Birim Müdürü ve \%8,57'sinin uzman olduğu Tablo'1 de görülmektedir.

Tablo 2: Katılımcıların Kurumdaki Çalışma Süreleri

\begin{tabular}{l|ll}
\hline \multicolumn{3}{c}{ Kurumdaki Çalışma Süreleri } \\
\hline Çalışma Süresi & Frekans & $\%$ \\
\hline 5 yıldan az & 8 & 7,62 \\
$5-10$ yıl arası & 15 & 14,29 \\
$11-15$ yıl arası & 40 & 38,10 \\
$16-20$ yıl arası & 9 & 8,57 \\
20 yıldan fazla & 33 & 31,43 \\
\hline Toplam & 105 & 100,00 \\
\hline
\end{tabular}

Anket yapılan yöneticilerin kurumdaki çalışma süreleri incelendiğinde $\% 7,62$ 'sinin 5 yıldan az, \%14,29'unun 5-10 yıl, \%38,10'nun 11-15 yıl, \%8,57'sinin 16-20 yıl, \%31,43'nün 20 yıldan fazla olduğu Tablo' 2 de görülmektedir.

Araştırma yapılan Tarım Kredi Kooperatiflerinde örgütsel performans değerlendirmede kurumsal karne yöntemi kullanılmaktadır. Araştırmaya katılan yöneticilerin \%77,14'ü kullanılan kurumsal karnenin yetersiz olduğunu, $\% 22,86$ 'sı ise yeterli olduğunu belirtmiştir. Mevcut kurumsal karnenin sadece finansal boyuta ilişkin amaç ve hedeflerden, bu hedeflere ulaşlıp ulaşılmadığını test edecek ölçütlerden oluştuğundan yetersiz olduğu yöneticiler tarafından ifade edilmiştir.

Tarımsal kooperatiflerin finansal boyuttaki stratejik amaç ve hedefleri kooperatif faaliyetleri, gelir artışı, faaliyetlerin verimliliği ve güçlü finansal yapı olmak üzere dört ana başlıkta toplanmıştır (Tablo.2). Kooperatif faaliyetleri kapsamında satışlardaki artışı katılımcıların \%36,19’u önemli ve \%59,05'i çok önemli olarak görmektedir. Gelirlerdeki artış ise katılımcıların \%25,71'i tarafından önemli ve \%71,43'ü tarafından çok önemli görülmektedir. Tarımsal kooperatiflerin faaliyetlerinin verimliliği hedefi doğrultusunda alacakların tahsilatındaki etkinliği katılımcıların $\% 14,29$ 'u önemli ve $\% 85,71$ 'i çok önemli, verimliliğin arttırılmasını ise \%37,14'ü önemli, $\% 60,95$ 'i çok önemli olarak görmektedir. Tarımsal kooperatiflerde güçlü bir finansal yapının 
oluşturulabilmesi için belirlenen amaçlardan sermaye tahsilatını katılımcıların \%9,52'si orta derece önemli, $\% 26,67$ 'si önemli ve $\% 63,81^{\prime} i$ çok önemli, finansal yapının güçlendirilmesini $\% 27,62$ 'si önemli, \%70,48'i çok önemli olarak görmektedir. Kullanılabilir öz kaynaklar ise katılımcıların \%21,90'ı tarafından önemli, \%76,19'u tarafından ise çok önemli görülmektedir. Finansal boyutta gelirlerdeki artış ve alacakların tahsilatındaki etkinlik stratejik amaç ve hedef olarak ön plana çıkmaktadır.

Tablo 3: Finansal Boyuttaki Amaç ve Hedeflerin Neler Olabileceğine Yönelik Verilen Cevapların Dağılımı

Tarımsal Kooperatiflerin Stratejik Amaç ve Hedefleri Neler OImalıdır?
Satışlarda Artış

Gelir Artışı

Gelirlerdeki Artış

Faaliyetlerin Verimliliği

Alacakların Tahsilatındaki Etkinlik

Verimliliğin Arttırılması

Güçlü Finansal Yapı

Sermaye Tahsilatı

Finansal Yapının Güçlendirilmesi

Kullanılabilir Öz kaynaklar
Kooperatif Faaliyetleri

\begin{tabular}{|c|c|c|c|c|c|c|c|c|c|}
\hline & 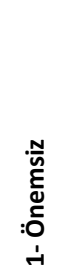 & & 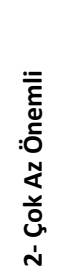 & & 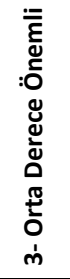 & & 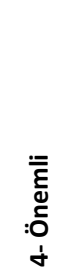 & & 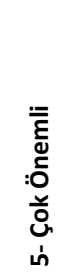 \\
\hline f & $\%$ & $f$ & $\%$ & $f$ & $\%$ & f & $\%$ & $f$ & $\%$ \\
\hline 0 & 0,00 & 0 & 0,00 & 5 & 4,76 & 38 & 36,19 & 62 & 59,05 \\
\hline 0 & 0,00 & 0 & 0,00 & 3 & 2,86 & 27 & 25,71 & 75 & 71,43 \\
\hline 0 & 0,00 & 0 & 0,00 & 0 & 0,00 & 15 & 14,29 & 90 & 85,71 \\
\hline 0 & 0,00 & 0 & 0,00 & 2 & 1,90 & 39 & 37,14 & 64 & 60,95 \\
\hline 0 & 0,00 & 0 & 0,00 & 10 & 9,52 & 28 & 26,67 & 67 & 63,81 \\
\hline 0 & 0,00 & 0 & 0,00 & 2 & 1,90 & 29 & 27,62 & 74 & 70,48 \\
\hline 0 & 0,00 & 0 & 0,00 & 2 & 1,90 & 23 & 21,90 & 80 & 76,19 \\
\hline
\end{tabular}

Ortak boyutunda stratejik amaç ve hedefler ortak kazanma, ortakları elde tutma ve ortak memnuniyeti olmak üzere üç grupta ele alınmıştır (Tablo 3). Tarımsal kooperatiflerin ortak kazanma amacı doğrultusunda ortak kitlemizi tanımak katılımcıların \%19,05'i tarafından önemli ve \%80,95'i tarafından çok önemli olarak değerlendirilmektedir. Ortak kayıplarını en aza indirmek amacını ise katılımcıların $\% 27,62$ ' si önemli ve $\% 72,38^{\prime}$ i çok önemli, yeni ortaklar kazanmak amacını ise \%16,19'u önemli ve \%83,81'i çok önemli görmektedir. Ortakları elde tutma amacı kapsamında ortakları sadakati yüksek ortağa dönüştürmeyi katılımcıların \%38,10’u önemli, \%61,90'ı çok önemli, ortak ürünlerinin değerlendirilmesini katılımcıların \%39,05'i önemli, $\% 59,05$ 'i çok önemli olarak görmektedir. Ortakların memnuniyetinin sağlanması amacı doğrultusunda kooperatif ortak ilişkilerini geliştirmek katılımcılar tarafından \%38,10 önemli, \%61,90 çok önemli, ortak tatminini sağlamak \%38,10 önemli, \%60,95 çok önemli, ortakları tarımsal alanda yaşanan değişimler konusunda bilgilendirmek $\% 41,90$ önemli, $\% 58,10$ çok önemli olarak görülmektedir. Ortak boyutunda öne çıkan stratejik amaç ve hedefler yeni ortaklar kazanmak, ortak kitlemizi tanımak ve ortak kayıplarını en aza indirmek olarak sıralanmaktadır. 
Bir Kooperatif İşletmesinin Stratejik Amaç ve Hedefleri Neler Olmalıdır?

\section{Ortak Kazanma}

Ortak Kitlemizi Tanımak

Ortak Kayıplarını En Aza İndirmek

Yeni Ortaklar Kazanmak

Ortakları Elde Tutma

Ortakları Sadakati Yüksek Ortağa Dönüştürmek

Ortak Ürünlerinin Değerlendirilmesi

Ortak Memnuniyeti

Kooperatif Ortak İlişkilerini Geliştirmek

Ortak Tatminini Sağlamak

Ortakları Tarımsal Alanda Yaşanan Değişimler

Konusunda Bilgilendirmek

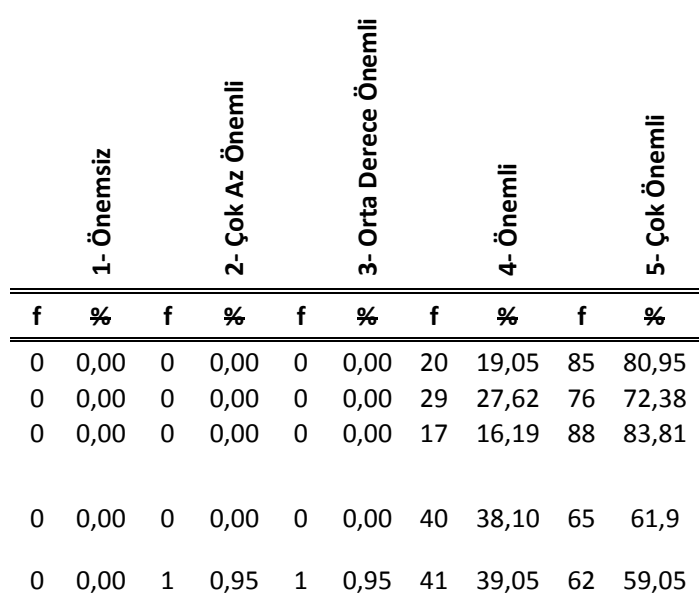

$\begin{array}{llllllllll}0 & 0,00 & 0 & 0,00 & 0 & 0,00 & 40 & 38,10 & 65 & 61,9 \\ 0 & 0,00 & 0 & 0,00 & 1 & 0,95 & 40 & 38,10 & 64 & 60,95 \\ 0 & 0,00 & 0 & 0,00 & 0 & 0,00 & 44 & 41,90 & 61 & 58,1\end{array}$

Öğrenme ve gelişme boyutunda stratejik amaç ve hedefler beşeri sermaye, teknoloji sermayesi ve örgütsel sermaye olmak üzere üç grupta ele alınmıştır (Tablo 4). Beşeri sermaye kapsamında değerlendirilen çalışanların tatminini artırmayı katılımcıların \%31,43'ü önemli, $\% 68,57$ 'si çok önemli, algılanan hizmet kalitesini ve hizmet üretim becerilerini geliştirmeyi, yeni yetenekler kazandırmayı \%53,3'ü önemli ve \%46,67'si çok önemli görmektedir. Çalışanların yönetime katılımının arttırılmasını katılımcıların \%39,05'i önemli ve \%57,14'ü çok önemli olarak değerlendirirken ortak memnuniyetini destekleyen yeni hizmet, teknoloji liderliği amacını ise katılımcıların \%37'14'ü önemli, \%58,1'i çok önemli görmektedir. Örgütsel sermaye kapsamında bireysel ve kurumsal uyumun arttırıması katılımcıların \%34,29'u tarafından önemli, \% 62,86'sı tarafından çok önemli görülmektedir. Öğrenme ve gelişme boyutunda çalışanların tatmini arttırmak ile bireysel ve kurumsal uyumun arttırılması katılımcıların büyük çoğunluğu tarafından öne çıkarılan stratejik amaç ve hedefler arasında yer almaktadır. 
Tablo 5: Öğrenme Ve Gelişme Boyutundaki Amaç ve Hedeflerin Neler Olabileceğine Yönelik Verilen Cevapların Dağılımı

Bir Kooperatif İşletmesinin

Stratejik Amaç ve Hedefleri Neler Olmalıdır?

Beşeri Sermaye

Çalışanların Tatminini Arttırmak

Algılanan Hizmet Kalitesini Ve Hizmet Üretim Becerilerini Geliştirmek- Yeni Yetenekler Kazandırmak

Çalışanların Yönetime Katılımının Arttırılması

Teknoloji Sermayesi

Ortak Memnuniyetini Destekleyen

Yeni Hizmet-Teknoloji Liderliği

Örgütsel Sermaye

Bireysel ve Kurumsal Uyumun Arttırılması

\begin{tabular}{|c|c|c|c|c|c|c|c|c|c|}
\hline & 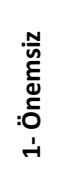 & & 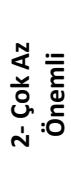 & & 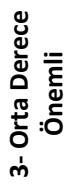 & & 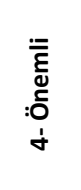 & & 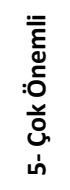 \\
\hline$f$ & $\%$ & $f$ & $\%$ & $f$ & $\%$ & $f$ & $\%$ & $f$ & $\%$ \\
\hline 0 & 0,00 & 0 & 0,00 & 0 & 0,00 & 33 & 31,43 & 72 & 68,57 \\
\hline 0 & 0,00 & 0 & 0,00 & 0 & 0,00 & 56 & 53,33 & 49 & 46,67 \\
\hline 0 & 0,00 & 0 & 0,00 & 4 & 3,81 & 41 & 39,05 & 60 & 57,14 \\
\hline 0 & 0,00 & 0 & 0,00 & 5 & 4,76 & 39 & 37,14 & 61 & 58,1 \\
\hline 0 & 0,00 & 0 & 0,00 & 3 & 2,86 & 36 & 34,29 & 66 & 62,86 \\
\hline
\end{tabular}

Tarımsal kooperatiflerin iç süreçler boyutundaki stratejik amaç ve hedefler operasyonlar süreci ve satış sonrası hizmetler olmak üzere iki grupta ele alınmıştır (Tablo 5). Çalışanların yaşam kalitesinin arttırılması katılımcıların \%32,38'si tarafından önemli, \%67,62'si tarafından çok önemli olarak ifade edilmektedir. Kooperatif bölge birliği arasındaki koordinasyonu arttırmayı katılımcıların \%38,10'u önemli, \%59,05'i çok önemli görmektedir. Devlet destekli kullandırılan kredi oranını arttırmayı katılımcıların \%36,19'u önemli, \%58,1'i çok önemli, işletme içi iletişimin geliştirilmesini katılımcıların \%46,67'si önemli, \%50,48'i ise çok önemli görmektedir. Ürünlerin çapraz satışını attırmak katılımcıların \%39,05'i tarafından önemli, \%59,05'i tarafından çok önemli görülmektedir. Satış sonrası hizmetler kapsamında satış sonrası iletişimi sürdürmek katılımcıların \%40’ı tarafından önemli, \%57,14'ü tarafından çok önemli olarak değerlendirilmektedir. Kurumsal karnenin bu boyutunda çalışanların yaşam kalitesinin arttırılması öne çıkan stratejik amaç ve hedef olarak katılımcılar tarafından ifade edilmektedir.

Tablo 6: iç Süreçler Boyutundaki Amaç ve Hedeflerin Neler Olabileceğine Yönelik Verilen Cevapların Dağılımı

\begin{tabular}{|c|c|c|c|c|c|c|c|c|c|c|}
\hline $\begin{array}{l}\text { Bir Kooperatif işletmesinin } \\
\text { Stratejik Amaç ve Hedefleri Neler Olmalıdır? }\end{array}$ & & $\begin{array}{l}\text { NN } \\
\text { है } \\
\mathbb{d} \\
: 0 \\
\dot{H}\end{array}$ & & 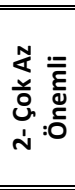 & & 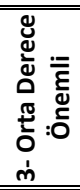 & & 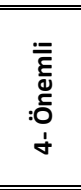 & & 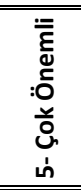 \\
\hline Operasyonlar Süreci & 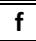 & $\%$ & 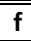 & $\%$ & $f$ & $\%$ & $f$ & $\%$ & $f$ & $\%$ \\
\hline Çalışanların Yaşam Kalitesinin Arttırılması & 0 & 0,00 & 0 & 0,00 & 0 & 0,00 & 34 & 32,38 & 71 & 67,62 \\
\hline $\begin{array}{l}\text { Kooperatif- Bölge Birliği Arasındaki } \\
\text { Koordinasyonu Arttırmak }\end{array}$ & 0 & 0,00 & 0 & 0,00 & 3 & 2,86 & 40 & 38,10 & 62 & 59,05 \\
\hline $\begin{array}{l}\text { Devlet Destekli Kullandırılan } \\
\text { Kredi Oranını Arttırmak }\end{array}$ & 0 & 0,00 & 2 & 1,90 & 4 & 3,81 & 38 & 36,19 & 61 & 58,1 \\
\hline İşletme İçi İletişimin Geliştirilmesi & 0 & 0,00 & 0 & 0,00 & 3 & 2,86 & 49 & 46,67 & 53 & 50,48 \\
\hline Ürünlerin Çapraz Satışını Arttırmak & 0 & 0,00 & 0 & 0,00 & 2 & 1,90 & 41 & 39,05 & 62 & 59,05 \\
\hline \multicolumn{11}{|l|}{ Satış Sonrası Hizmetler } \\
\hline Satış Sonrası İletişimi Sürdürmek & 0 & 0,00 & 0 & 0,00 & 3 & 2,86 & 42 & 40,00 & 60 & 57,14 \\
\hline
\end{tabular}


Tarımsal kooperatiflerin kurumsal performans karnesinde belirtilen amaç ve hedeflere ulaşılıp ulaşılmadığını test edecek ve katılımcılar tarafından önemli görülen ölçütler şu şekildedir;

Finansal boyut kapsamında satışlarda artışı test edecek ölçüt olarak 'toplam satışların artış oranı', gelirlerdeki artışı test edecek ölçütler 'satış gelirlerindeki artış oranı ve sigorta gelirlerindeki artış oranı', alacakların tahsilatındaki etkinlik amacını test edecek ölçütler 'cari tahsilat oranı ve genel tahsilat oranı', verimliliğin arttırılmasını test edecek ölçüt 'toplam gelirlerin/toplam giderlere oranı', sermaye tahsilatını test edecek ölçüt 'ödenmiş sermaye artış oranı', finansal yapının güçlendirilmesini test edecek ölçütler 'öz kaynakların/yabancı kaynaklara oranı', kullanılabilir öz kaynaklar amacını test edecek ölçüt olarak 'kullanılabilir öz kaynak artış oranı' olarak belirtilmektedir.

Ortak boyutu kapsamında ortak kitlemizi tanımak amacını test edecek ölçüt olarak 'sadıkdevamlı ortak oranı', ortak kayıplarını en aza indirmeyi test edecek ölçüt 'kaybedilen ortak sayısı', yeni ortaklar kazanma amacını test edecek ölçüt olarak 'yeni ortak sayısı', ortakları sadakati yüksek ortağa dönüştürmeyi test edecek ölçüt 'ortak sayısındaki artış', ortak ürünlerinin değerlendirilmesini test edecek ölçütler 'ürün değerlendirme kapsamında ürün alınan ortak sayısı ve sözleşmeli üretim yaptırılan ortak sayısı', kooperatif ortak ilişkilerini geliştirmeyi test edecek ölçüt 'ortak ziyaret sayısı', ortak tatminini sağlamak amacını test edecek ölçüt 'ortak memnuniyet anketi', ortakları tarımsal alanda yaşanan değişim konusunda bilgilendirmek amacını test edecek ölçüt olarak 'uygulamalı eğitim verilen ortak sayısı' olarak ifade edilmektedir.

Öğrenme ve gelişme boyutu kapsamında çalışanların tatminini artırmak amacını test edecek ölçüt 'iş gören tatmin anketi', algılanan hizmet kalitesini ve hizmet üretim becerilerini geliştirmek-yeni yetenekler kazandırmak amacını test edecek ölçütler 'müşteri ilişkileri, muhasebe mevzuat vb. konularda eğitimli personelin oranı ve eğitimlerin çalışanlar üzerindeki etkisi (eğitim sonu memnuniyet anketi)', çalışanların yönetime katılımının arttırılmasını test edecek ölçüt 'alınan öneri sayısı/çalışan sayısı', ortak memnuniyetini destekleyen yeni hizmet- teknoloji liderliğini test edecek ölçüt 'yeni geliştirilen teknoloji-ürün-hizmet sayısı', bireysel ve kurumsal uyumun arttırılmasını test edecek ölçüt başarııı 'çalışanlara verilen ödüllerin sayısı 'olarak belirtilmektedir.

Iç süreçler boyutu kapsamında, çalışanların yaşam kalitesinin arttırılmasını test edecek ölçüt 'çalışma yaşam kalitesi anketi', kooperatif-bölge birliği arasındaki koordinasyonu arttırmak amacını test edecek ölçüt 'bölge kooperatif arasındaki çalışma uyumu anketi', devlet destekli kullanılan kredi oranını arttırmak amacını test edecek ölçütler 'devlet destekli kullandırılan kredi/kullandırılan toplam kredi oranı ve devlet destekli kredi kullanılan ortak sayısı/kredi kullanan toplam ortak sayısı', işletme içi iletişimin geliştirilmesini test edecek ölçüt işletme 'içi iletişimin etkinliği anketi', ürünlerin çapraz satışını arttırmak amacını test edecek ölçüt 'çapraz satışların oranı', satış sonrası iletişimi sürdürmek amacını test edecek ölçüt 'satış sonrası iletişime geçilerek memnuniyet anketi düzenlenen ortak sayısı' olarak ifade edilmektedir. 
Tablo 7: Kooperatiflerin Kurumsal Performans Karnesinde Önemli Görülen Amaç ve Ölçütler

Bir Kooperatif İşletmesinin

Stratejik Amaç ve Hedefleri Neler Olmalıdır?
Bu Hedeflere Ulaşılıp Ulaşıımadığını Test Edecek Ölçütler Neler Olmalıdır?

\begin{tabular}{|c|c|}
\hline \multicolumn{2}{|l|}{ Finansal Boyut } \\
\hline Satışlarda Artış & Toplam Satışların Artış oranı \\
\hline Gelirlerdeki Artış & Satış Gelirlerindeki Artış Oranı \\
\hline & Cari Yıl Tahsilat Oranı \\
\hline Alacakıarın Iahsılatındakı Etkınlık & Genel Tahsilat Oranı \\
\hline Finansal Yapının Güçlendirilmesi & Öz kaynakların Yabancı Kaynaklara Oranı \\
\hline Kullanılabilir Öz kaynaklar & Kullanılabilir Öz kaynak Artış Oranı \\
\hline \multicolumn{2}{|l|}{ Ortak Boyutu } \\
\hline Ortak Kitlemizi Tanımak & Sadık- Devamlı Ortak Oranı \\
\hline Ortak Kayıplarını En Aza İndirmek & Kaybedilen Ortak Sayısı \\
\hline Yeni Ortaklar Kazanmak & Yeni Ortak Sayısı \\
\hline Ortakları Sadakati Yüksek Ortağa Dönüştürmek & Ortak Sayısındaki Artış Oranı \\
\hline Ortak Ürünlerinin Değerlendirilmesi & $\begin{array}{l}\text { Ürün Değerlendirme Kapsamında Ürün Alınan Or- } \\
\text { tak Sayısı }\end{array}$ \\
\hline 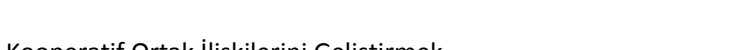 & Ortak Ziyaret Sayısı \\
\hline 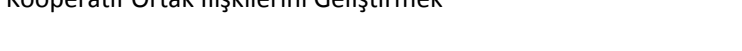 & Sorun/Şikayetleri Çözümleme Başarısındaki Oran \\
\hline \multicolumn{2}{|c|}{ İç Süreçler Boyutu } \\
\hline Çalışanların Yaşam Kalitesinin Artırılması & Çalışma Yaşam Kalitesi Anketi \\
\hline \multirow{2}{*}{ Devlet Destekli Kullandırılan Kredi Oranını Artırmak } & $\begin{array}{l}\text { Devlet Destekli Kullandırılan Kredi/Toplam Kullan- } \\
\text { dırılan Kredi }\end{array}$ \\
\hline & $\begin{array}{l}\text { Devlet Destekli Kredi Kullanan Ortak Sayısı/Top- } \\
\text { lam Kredi Kullanan Ortak Sayısı }\end{array}$ \\
\hline Satış Sonrası İletişimi Sürdürmek & $\begin{array}{l}\text { Satış Sonrası İletişime Geçilerek Memnuniyet An- } \\
\text { keti Düzenlenen Ortak Sayısı }\end{array}$ \\
\hline \multicolumn{2}{|c|}{ Öğrenme ve Gelişme Boyutu } \\
\hline Çalışanların Tatmini Artırmak & İş gören Tatmin Anketi \\
\hline \multirow{2}{*}{$\begin{array}{l}\text { Algılanan Hizmet Kalitesini Ve Hizmet Üretim Becerilerini Geliş- } \\
\text { tirmek- Yeni Yetenekler Kazandırmak }\end{array}$} & $\begin{array}{l}\text { Müşteri İlişkileri, Muhasebe Mevzuat Vb. Konu- } \\
\text { larda Eğitimli Personelin Oranı }\end{array}$ \\
\hline & $\begin{array}{l}\text { Eğitimlerin Çalışanlar Üzerindeki Etkisi (Eğitim } \\
\text { Sonu Memnuniyet Anketi) }\end{array}$ \\
\hline Çalışanların Yönetime Katılımının Arttırılması & Alınan Öneri Sayısı / Çalışan Sayısı \\
\hline Bireysel Ve Kurumsal Uyumun Arttırılması & Başarılı Çalışanlara Verilen Ödüllerin Sayısı \\
\hline
\end{tabular}

Örgütsel performansı çok boyutlu olarak ele alan kurumsal performans karnesinde yer alan amaç ve ölçütler doğru olarak belirlenirse kooperatifler açısından etkin bir performans ölçme 
ve değerlendirme sistemi kurulmuş olacaktır. Bu bağlamda kooperatifler için oluşturulan kurumsal performans karnesinde yer alacak her bir boyuta ilişkin amaçlar ve bu amaçları test edecek ölçütler Tablo 7' de gösterilmektedir.

\section{Sonuç ve Öneriler}

Tarım sektörü ülkeler açısından stratejik öneme sahip olup, özellikle az gelişmiş ve gelişmekte olan ülkelerde milli gelir ve istihdama olan katkısı yadsınamaz bir gerçektir. Ancak tarım sektöründe geçmişten süre gelen sorunlar halen devam etmektedir. Bu sorunların başında işletmelerin ölçek büyüklüğü gelmektedir. Büyük çoğunluğu aile işletmeciliği şeklinde yürütülen tarımsal faaliyetlerde üreticiyi koruyan önemli yapıların başında kooperatifler gelmektedir. Bu bağlamda tarımsal girdilerin üreticilere uygun fiyat ve şartlarda temin edilmesinde, üreticilerin ürünlerinin pazara ulaştırılmasında tarımsal kooperatifler önemli bir yere sahiptir. Bu noktadan hareketle çalışmada tarımsal kooperatif işletmelerinin geleceği hedefleyebilmesi için kurumsal performansta artış sağlayacak, kendilerine özgü, çok boyutlu bir ölçme ve değerlendirme sisteminin kurumsal performans karnesi yöntemiyle ölçülmesini sağlayacak örnek bir model önerisi geliştirilmesi amaçlanmıştır.

Tarımsal kooperatiflerde kurumsal performans karnesi oluşturulmasına yönelik olarak bu çalışmada kooperatif işletmelerinin stratejik amaç ve hedeflerinin ve bu amaç ve hedefleri test edecek ölçütlerin neler olabileceği belirlenmeye çalışıımıştır. Araştırma kapsamında katılımcıların büyük çoğunluğunu (\%77) kurumda uygulanan yalnızca finansal hedefler ve bu hedeflerin gerçekleşip gerçekleşmediğini gösteren performans karnesinin yetersiz olduğunu belirtmeleri çalışmanın gerekliliğini ortaya koymaktadır.

Tarım Kredi Kooperatifleri işlevleri itibariyle üreticilere kredi temin eden bir kurum olmanın yanı sıra farklı hizmetler sağlayan çok amaçlı entegre bir hizmet organizasyonu olduğundan araştırma kapsamında kurumsal performans karnesinde finans ve ortak boyutu ön plana çıkmaktadır.

Tarımsal kooperatiflerin faaliyetlerinin temelini satışlar, gelirlerini ise bu satışlardan elde edilen satış gelirleri oluşturduğundan finans boyutunda satış ve gelirlerdeki artış önemli görülen amaç ve hedefler arasında yer almaktadır. Bu boyutta yer alan faaliyetlerin verimliliği ile güçlü finansal yapı kapsamında yer alan stratejik amaç ve ölçütleri birlikte değerlendirmek gerekmektedir. Nitekim tarımsal kooperatiflerin her biri ayrı bir işletme olarak faaliyette bulunduklarından finansal açıdan güçlü bir yapıya sahip değildirler. Kooperatiflerin finansmanı ortaklarının kayıt olurken bir kısmını peşin kalanını ise taksitle ödemeyi taahhüt ettikleri sermaye ve bankalardan kullanılan kredilerden oluşmaktadır. Bu bağlamda kısıtlı imkânlarla ortaklarına hizmet eden kooperatifler alacaklarını zamanında tahsil edemediğinde ekonomik açıdan büyük sıkıntılar yaşayabilmektedir. Bunun için kooperatiflerin ortaklarına daha iyi hizmet sunabilmesi, devamlılığını sağlayabilmesi finansal yapısının güçlü olması ve alacaklarını zamanında tahsil edebilmesi ile mümkün olacaktır.

Ortak boyutunda yer alan stratejik amaç ve hedefler özellikle tarım sektöründe yaşanan daralma ve buna bağlı olarak her geçen gün üretici sayısında yaşanan azalma nedeniyle tarımsal kooperatiflerin faaliyetlerini devam ettirebilmesi için önemlidir. Sektörde yaşanan daralma rekabeti de beraberinde getirdiğinden kooperatiflerin ortaklarını kaybetmemesini beraberinde yeni ortaklar kazanmasını gerektirmektedir. Nitekim yeni ortak kazanmanın maliyeti mevcut ortağı muhafaza etmekten daha yüksek olacağından öncelikli olarak mevcut ortakları tanıyarak 
intiyaçlarını en uygun koşullarda tedarik ederek ortak tatmini sağlanmalıdır. Ortakları elde tutmak ve kooperatif ortak ilişkilerini geliştirmek için ortakların üretmiş oldukları ürünlerin kooperatif aracılı̆̆ıla pazara sunulması gerekmektedir. Bu doğrultuda ortakların ürünlerinin para etmemesi, aracıların üreticilerden daha çok kazanması vb. sorunlar ortadan kalkacaktır. Dolayısıyla ortakların memnuniyeti artacaktır. Kooperatif açısından ise ürünlerin kooperatifler aracılığıyla pazara sunulması nakit akışını da kooperatifler üzerinden gerçekleştireceğinden kooperatif alacaklarının tahsil edilmesinde etkin rol oynayacaktır.

Kurumsal performans karnesinin boyutları arasında bir dengenin bulunması gerekmektedir. Bu denge işletmelerin yapısına, faaliyette bulunduğu sektörlere göre farklılıklar gösterebilir. Nitekim çalışmada tarımsal kooperatiflerde öğrenme ve gelişme boyutu ile iç süreçler boyutunun finans ve ortak boyutuna göre arka planda kaldığı görülmektedir. Fakat beşeri sermaye olarak ifade edilen çalışanlar, mali yapısının iyi olmaması veya ekonomik koşullardan dolayı çalışan sayısının az olduğu ve çok sayıda farklı işin bir veya birkaç kişi tarafından yapıldığı kooperatifler için çok önemli bir unsurdur. Kooperatiflerde çalışan sayısının az olması iş tanımlarının yapılmasını ve çalışanların belirli alanlarda uzmanlaşmasını engellemektedir. Bundan dolayı kooperatiflerde yürütülen faaliyetlere ilişkin olarak çalışanlara belirli aralıklarla eğitimler verilmesi gerekmektedir. Öğrenme ve gelişme boyutu kapsamında çalışanların yönetime katılımının arttırılması özellikle sahada yaşanan sıkıntıların, çözülmesi gereken problemlerin yerinde tespit edilerek çözüm önerilerinin geliştirilmesi bakımından önemlidir. Son olarak iç süreçler boyutu bağlamında değerlendirme yapıldığında, kooperatifçilik ilkeleri içerisinde yer alan kooperatifler arası yardımlaşma ve dayanışmaya doğrultusunda kurum içerisinde veya diğer kooperatiflerle iletişimin sürdürülmesi gereği ortaya çıkmaktadır. Bununla birlikte kooperatiflerin üreticiler için tedarik ettikleri ürünler bölge birlikleri vasıtasıyla temin edildiğinden üreticilere ihtiyaç duydukları girdileri en uygun zaman ve koşullarda sunabilmek için bölge birliği ve kooperatifler arasında etkin bir koordinasyon sağlanması gerekmektedir.

Kurumsal performans karnesi yöntemini geleneksel performans yönetim sistemlerinden ayıran en önemli fark finansal performans ölçütleri ile birlikte finansal olmayan performans ölçütlerini de dengeli bir şekilde kullanmasıdır. Bu doğrultuda tarımsal kooperatiflerde etkin bir performans yönetim sistemi için finansal ve ortak boyutu ile birlikte, öğrenme ve gelişme boyutu ve iç süreçler boyutuna da dengeli bir şekilde sisteme dâhil etmeleri gerekmektedir. Kooperatifçilik faaliyeti çalışanların büyük özverisiyle başarıya ulaşacağından tarımsal kooperatiflerde öğrenme ve gelişme boyutuna daha çok önem verilmelidir.

Örgütsel performansın kurumsal karne yöntemiyle ölçülmesine yönelik olarak kooperatifçilik alanında herhangi bir çalışmaya rastlanılmamış olması bu çalışmanın özellikle tarımsal kooperatiflerin etkin ve verimli bir şekilde çalışarak, faaliyetlerinin sürekliliğini sağlayacak bir örgütsel performans sisteminin kooperatiflerde uygulanabilmesine ve tarımsal kooperatiflerin geleceğine önemli bir katkı sağlayacağı düşünülmektedir. 


\section{Eskişehir Osmangazi Üniversitesi IïB Dergisi}

\section{Kaynaklar}

Albright,Thomas; Christopher M.Burgess; Davis Stan (2015), " The Balanced Scorecard and Twenty-First-Century Thoughts on Motivation.", Journal of Corporate Accounting \& Finance Vol:23, No.1: 73-80

Bose Ranjit (2004), “Knowledge Management Metrics. Industrial Management \& Data Systems”, Vol:104, No. 6: 457468.

Erkul, Hüseyin; Dereköy, Feyza; Erden Ayhün, Sena (2013), "Yükseköğretim Kurumlarında Dengeli Ölçüm Kartı Geliştirilmesi: Çanakkale Sosyal Bilimler Meslek Yüksekokulu Örneği”, Yüksek Öğretim ve Bilim Dergisi, Vol.5, No.2: 203-213

Gencer, Cevriye; Çetin, Tuğba (2011)," Kurumsal Performans Karnesi ve Havacılık Sektöründe Bir Uygulama", Savunma Bilimleri Dergisi, Cilt.10, Sayı.2: 105-121

Gençay, i.Cemal (2014), “Termal Turizm İşletmelerinde Kurumsal Performans Karnesi Oluşturulmasına Yönelik Model Önerisi", Seyahat ve Otel İşletmeciliği Dergisi, Vol.11, No.1: 70-89

Griffiths, John (2003), "Balanced Scorecard Use In New Zealand Goverment Departments and Crown Entities", Australian Journal Of Public Administration

GTB (2012), Türkiye Kooperatifçilik Stratejisi ve Eylem Planı, Ankara

ICA 1995, “ICA Adopts New Co-Operative Principles “, Victorian Co-operative News, Vol.2, No,3: 1-4

Kaplan, Robert; Norton David (2015), Kurumsal Karne Şirket Stratejisinin Eyleme Dönüştürmek. Çeviren: Serra Egeli, İstanbul: Sistem Kitabevi

Kaplan, Robert S; Norton David (1992), "The Balanced Scorecard - Measures That Drive Performance”, Harvard Business Review, Vol:70, No.1: 71-79,

Kaplan, Robert S; David Norton (1993), "Putting the Balanced Scorecard to Work." Harvard Business Review Vol:71, No. 5: 2- 17

Lawrie,Gavin; Cobbold lan (2004), "Third-Generation Balanced Scorecard: Evolution of Aneffective Strategic Control Tool", International Journal of Productivity and Performance Management Vol:53 No.7: 611-623

Letza, Stephen R (1996), “The Design and_mplementation of The Balanced Business Scorecard”, Business Process ReEngineering and Management Journal, Vol:2, No.3: 54-76

MacPherson, Ian (1994), "The Co-operative Identity in the Twenty-First Century". A background paper. Review of International Co-operation, Vol:87, No.3: 8-26

Öztuna, Barış (2014),"Sosyal Güvenlik Kurumunda Kurumsal Karne Modeli", ÇSGB Çalışma Dünyası Dergisi, Vol.2, Issue.3: 22- 45

Pazarçeviren, Yüksel; Karakaya, Gencay; Karakaya, Elif (2015),"Sivil Toplum Kuruluşlarında Kurumsal Karne Uygulama Süreci Önerisi", Sosyal Bilimler Dergisi, Vol. VIII, No.1:172-195

Perkins, Mike; Grey Anna; Remmers Helge (2014),"What do we reaally mean by Balanced Scorecard”, International Journal of Productivity and Performance Management, Vol:63, No.2: 148-169

Polat, Hüseyin (2017), "Yarının İşletmesi Kooperatif" Ankara: Orkide Matbaası,

Russell, Levi A; Briggeman Brian C; Featherstone Allen M (2017), "Financial Leverage And Agency Costs İn Agricultural Cooperatives", Agricultural Finance Review, Vol:77, Issue.2: 312-323

Szabó, Gábor (2005), "Co-operative Identity: A Theoretical Concept For Economic Analysis of Practical Co-operation Dynamics", Studies in Agricultural Economics No.105: 5-22

Usta, Aydın (2012), "Kamu Örgütlerinde Kurumsal Karne Modeli ile Performans Yönetimi: Boyutlar ve Göstergeler", Amme Idaresi Dergisi, Cilt.45, Sayı.1: 99- 120

Yıldız, M.Selami; Kethüda, Önder; Kurutkan, M.Nurullah (2013), “Dengeli Ölçüm Kartı'nın Hastane İşletmelerinde Uygulanması: Örnek Olay Çalışması”, Atatürk Üniversitesi Iiktisadi ve Idari Bilimler Dergisi, Cilt.27, Sayı.4: 90- 110

Yılmaz, Recep, Gudil, Orhan(2016)," Makina İmalat Sektöründe Dengeli Sonuç Kartı Ve Bütçe Uygulaması”, Kastamonu iktisadi ve Idari Bilimler Dergisi, Sayı.12:481-497

Wake, Nicholas John (2015), "The Use Of The Balanced Scorecard To Measure Knowledge Work", International Journal of Productivity and Performance Management, Vol: 64, Issue, 4: 590-602

Wilson, Chris; Hagarty David; Gauthier Julie (2004), "Results using the balanced scorecard in the public sector", Journal of Corporate Real Estate, Vol:6, No.1: 53-64 